УДК $347-057.86$

DOI:

Василь Ротар, кандидат педагогічних наук, доцент кафедри техніки та засобів ичивільного захисту

Черкаського інституту пожежної безпеки імені Героїв Чорнобиля

Кирило Пасинчук, кандидат педагогічних наук, доцент кафедри економіки у сфері ияивільного захисту

Черкаського інституту пожежної безпеки імені Героїв Чорнобиля

\title{
ПРОФЕСІЙНА КУЛЬТУРА ФАХІВЦЯ У СФЕРІ ЦИВІЛЬНОГО ЗАХИСТУ ЯК ВЕКТОР УСПІХУ
}

Автором здійснено спробу з'ясувати сутність поняття "професійна культура фахівия у галузі цивільного захисту”; аргументовано, що професійну культуру фахівия у галузі цивільного захисту слід розглядати як складне особистісне утворення, ще складається з трьох компонентів: змістовний (уявлення про сутність понять “культура", “професійна культура”); емоиійно-мотиваційний (потреба в підвищенні рівня професійної культури); діяльнісний (здійснення професійної діяльності; дотримання вимог щодо усного та писемного мовлення; правильність оформлення ділової документаиії тощо).

Ключові слова: фахівець у сфері ичивільного захисту; професійна культура; рівні сформованості професійної культури; показники професійної культури; професійна етика.

Табл. 1. Рис. 1. Літ. 6.

Vasyl Rotar, Ph.D.(Pedagogy), Associate Professor of the Engineering and the Means of Civil Defense Department Cherkasy Institute of Fire Safety named after Heroes of Chornobyl Kyrylo Pasynchuk, Ph.D.(Pedagogy), Associate Professor of the Economy in the Sphere of Civil Protection Department Cherkasy Institute of Fire Safety named after Heroes of Chornobyl

\section{PROFESSIONAL CULTURE OF THE SPECIALIST IN THE FIELD OF CIVIL PROTECTIONASA SUCCESSFULVECTOR}

The author deals with the essence of the concept "professional culture of a specialist in the field of civil protection"; it is argued, that the professional culture of a specialist in the field of civil defense should be regarded as a complex personal formation consisting of the following components: content; emotional and motivational; and active.

The article proves that professional culture has a decisive influence on the development of professional competence of a future specialist in the field of civil protection in many areas: an adequate orientation of the cadet to the requirements of professional activity; the awareness of professional image; provision of a stable motivation of the professional self-improvement; creation of meaningful basis for the formation of new knowledge; creation of conditions for self-determination and self-realization; a constructive analysis and correction of practical activity.

The conducted analysis of the conducted research testifies the lack of formation of the professional culture of the students, which necessitates the development of a model of formation of professional culture of future specialists in the field of civil protection.

Keywords: a specialist in the sphere of civil protection; professional culture; the levels of formation of professional culture; the indicators of professional culture; professional ethics.

П остановка проблеми. В умовах глобальних змін у різних сферах життя сучасного суспільства вже недостатньо певного наборузнань, умінь і навичок у сфері цивільного захисту, оскільки зростає роль відповідальності фахівця за свої дії, усвідомлення наслідків для людей, соціального та природного середовища.

Як справедливо зазначає I. Цибулько, особливості професій у сфері цивільного захисту ставлять перед особистістю вимоги, реалізація яких забезпечить своєчасне та чітке виконання професійних обов' язків, знизить рівень помилкових дій, зменшить кількість аварійних ситуацій і катастроф [6].

Власне від правильності дій фахівця у сфері цивільного захисту залежить безпека людей, захист територій, населених пунктів; передбачення та вчасна ліквідація наслідків надзвичайних ситуацій; отримання достовірної інформації про ситуацію в районах надзвичайних ситуацій тощо. Важливим також залишається 
питання про роль навчання населення діям у надзвичайних ситуаціях. Зазначимо, що ефективність цього процесу залежить від сформованості професійних умінь і навичок фахівця, його здатності доносити інформацію, координувати дії суб'єктів забезпечення цивільного захисту тощо. А отже, мова йде про сформованість професійної культури фахівця у сфері цивільного захисту.

Сказане вище актуалізує потребу підвищення якості освітнього процесу, зумовлює необхідність посиленої уваги до питання професійної підготовки майбутніх фахівців у сфері цивільного захисту, а відтак - до проблеми формування їхньої професійної культури.

Аналіз останніх досліджень і публікацій. Сьогодні значна увага приділяється формуванню професійної культури майбутніх фахівців у закладі вищої освіти (Г. Дмитренко, В. Журавльов, І. Мельник, Л. Фільштейн та ін.).

Особливості підготовки майбутніх фахівців у сфері цивільного захисту висвітлюють О. Бурак, М. Горонескуль, І. Коваль, В. Садковий, І. Цибулько та ін.

Так, В. Садковий, М. Горонескуль акцентують особливу увагу на якості освітніх послуг, що надаються. 3 кожним роком кардинально змінюються погляди на мету, завдання та зміст вищої освіти, головною вимогою до якої стає здатність випереджати час та вчитися швидше, ніж змінюється світ [4].

I. Мельник [3], здійснюючи характеристику професійної культури спілкування майбутніх фахівців пожежної безпеки, зосереджує увагу на феномені спілкування як основи професійної діяльності майбутніх фахівців пожежної безпеки. Дослідники О. Бурак та І. Коваль висвітлюють особливості формування особистості майбутнього фахівця в умовах навчального процесу [2].

Питання морального самовдосконалення особистості фахівця служби цивільного захисту шляхом розвитку рефлексивних умінь під час навчання у закладах вищої освіти ДСНС України $\epsilon$ предметом пильної уваги Н. Вовк, Т. Кришталь [1] та ін.

Однак, попри значну кількість публікацій, присвячених особливостям підготовки майбутніх фахівців у сфері цивільного захисту, проблема формування професійної культури курсантів залишається поза увагою дослідників, що й зумовлює актуальність піднятої проблеми.

Мета статті полягає в аналізі компонентів та рівнів сформованості професійної культури фахівців у сфері цивільного захисту.
Виклад основного матеріалу. Професійна культура - це складне, багатомірне явище, що формується під впливом різних детермінант протягом усього процесу навчання. Незаперечним $\epsilon$ той факт, що професійна культура здійснює визначальний вплив на розвиток професійної компетентності майбутнього фахівця (в нашому випадку - фахівця у сфері цивільного захисту) в багатьох напрямах:

- адекватна орієнтація курсанта у вимогах до професійної діяльності;

- усвідомлення курсантом образу професійної діяльності;

- забезпечення стійкої мотивації професійного самовдосконалення;

- створення змістовного підгрунтя для формування нових знань;

- створення умов для самовизначення i самореалізації;

- конструктивний аналіз і коригування практичної діяльності.

У своєму дослідженні ми розглядаємо професійну культуру майбутнього фахівця у сфері цивільного захисту як сукупність навчальних досягнень, способів, прийомів, накопичення досвіду фахової діяльності, що впливає на особисте ставлення до професійної етики та розуміння необхідності володіння нею для успішного здійснення професійної діяльності.

Ми виходимо 3 того, що процес професійної підготовки майбутніх фахівців у сфері цивільного захисту має бути зорієнтований на сучасну парадигму освіти, суть якої полягає в орієнтації професійної освіти на задоволення потреб суспільства у висококваліфікованих фахівцях. Аспекти формування професійної культури, самовдосконалення при цьому займають особливе місце.

Погоджуємося, що формування професійної культури означає “переведення нормативної основи професійної діяльності в індивідуальний стиль ï виконання, що характеризується індивідуальним вибором засобів і способів цієі діяльності, підходами до ії проектування, а також мотивами, ціннісними орієнтаціями, особливостями процесу їі виконання" [5, 16 ].

Отже, професійна культура фахівця у сфері цивільного захисту може розглядатись як складне особистісне утворення, що складається 3 трьох компонентів: змістовний (уявлення про сутність понять “культура", “професійна культура"); емоційно-мотиваційний (потреба в підвищенні рівня професійної культури); діяльнісний (здійснення професійної діяльності; дотримання вимог щодо усного та писемного мовлення; 
правильність оформлення ділової документації тощо).

Критеріями сформованості професійної культури майбутніх фахівців у сфері цивільного захисту нами було визначено: сформованість знань про професійну культуру, яка визначалася відповідними показниками (поняття про сутність професійної діяльності фахівця у сфері цивільного захисту, фахові знання та знання про складові професійної культури, знайомство зі специфікою професійної діяльності в умовах надзвичайних ситуацій); мотивація на формування професійної культури (показниками якої є сформованість ціннісних орієнтацій, прагнення підвищувати рівень професійної культури, усвідомлення значимості професійної культури фахівця у сфері цивільного захисту); діяльнісна активність (оцінюється через показники активного використання на практиці професійних знань, дотримання професійної етики, правильність, грамотність оформлення ділової документації).

3 метою 3'ясування рівнів сформованості професійної культури майбутніх фахівців ми провели опитування курсантів Черкаського інституту пожежної безпеки імені Героїв Чорнобиля. У дослідженні взяло участь 126 курсантів. На основі даних, отриманих у результаті дослідження, ми спробували визначити загальний рівень сформованості професійної культури фахівця у сфері цивільного захисту. Нами було розроблено шкалу оцінювання. Залежно від ступеня прояву певних ознак кожного із показників ми визначили три рівні сформованості: високий, середній, низький.

Рівень сформованості професійної культури майбутніх фахівців у сфері цивільного захисту підраховувався таким чином: кожен курсант мав заповнити протокол на початку року. Методами визначення рівня сформованості професійної культури були спостереження, бесіди, анкетування, тестування курсантів. Шкала оцінювання сформованості професійної культури майбутніх фахівців у сфері цивільного захисту подана табл. 1.

Інформація про рівень сформованості професійної культури майбутніх фахівців у сфері цивільного захисту була одержана шляхом

незалежних характеристик, складених із урахуванням результатів самооцінювання курсантів, результатів екзаменаційної сесії, проходження різних видів практики; оцінювання викладачів.

Аналіз цих даних свідчить, що лише 18,9\% курсантів усвідомлюють значення професійної культури фахівця у сфері цивільного захисту. Володіючи знаннями про сутність професійної культури, прагнуть підвищити рівень професійної культури. Їхня установка на процес формування професійної культури дає стійкий позитивний емоційний стимул, здатність орієнтуватися в різних (а іноді - не стандартних) професійних (надзвичайних) ситуаціях. Вони усвідомлюють взаємозв”язок “професійна культура ефективність професійної діяльності”, чітко дотримуються правил оформлення ділової документації, орієнтуються на власну програму самовдосконалення. Курсанти цієї групи надають перевагу самостійним заняттям, пов'язаним із професійним вдосконаленням. Ці курсанти були віднесені до групи 3 високим рівнем сформованості професійної культури.

До групи з середнім рівнем сформованості професійної культури було віднесено $39 \%$ курсантів, які виявляють пасивно-позитивне ставлення до значимості професійної культури фахівця у сфері цивільного захисту. Вони мають достатні знання з фахових дисциплін, переважно розуміють необхідність дотримання професійної культури, однак усвідомленої потреби в цьому не виявляють. При оформлення ділової документації допускають помилки. Несистематично займаються самовдосконаленням (переважають зовнішні стимули), не завжди дотримуються правил професійної етики, хоча розуміють їх значимість. Хоча в курсантів цієї групи сформовано навички самовдосконалення, вони не завжди реалізуються на практиці.

У 42,1\% потребу у формуванні професійної культури сформовано недостатньо. Вони не мають чітких знань із фахових дисциплін та мають недостатні знання про професійну етику. Часто допускають помилки при оформленні ділової документації. Навички самовдосконалення

Таблиця 1.

Шкала оцінювання сформованості професійної культури майбутніх фахівців у сфері цивільного захисту

\begin{tabular}{|c|c|c|}
\hline Рівні сформованості & Оцінка & Бали \\
\hline Високий & 5 & $50-55$ \\
\hline Середній & 4 & $54-28$ \\
\hline Низький & 3 & $27-0$ \\
\hline
\end{tabular}




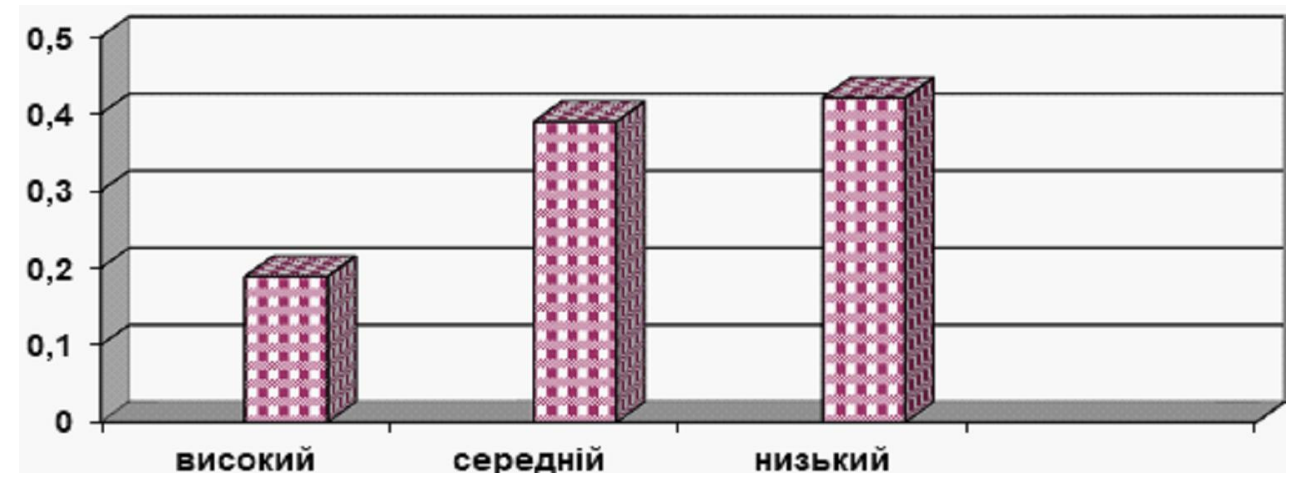

Рис. 1. Рівні сформованості професійної культури майбутніх фахівців у сфері цивільного захисту

сформовані частково і не завжди реалізуються на практиці, їхня поведінка визначається переважно зовнішніми стимулами. Ці курсанти увійшли до групи з низьким рівнем сформованості професійної культури.

Результати проведено дослідження представлено на рис. 1 .

Результати проведеного дослідження свідчать про недостатній рівень сформованості професійної культури фахівців у сфері цивільного захисту, а це, своєю чергою, про неготовність курсантів нести відповідальність за свої професійні рішення; опиратися на власні знання і вміння, а не на випадок; наявність ризику при виконанні професійних дій.

Аналіз спостережень, анкетування та даних опитування дає підставу стверджувати, що ефективність процесу формування професійної культури майбутніх фахівців у сфері цивільного захисту залежить від змістового наповнення освітнього процесу та прагнення курсантів підвищувати рівень професійної культури, дотримуватися професійної етики. Звідси робимо висновки про те, що потрібно урізноманітнювати форми та методи роботи 3 курсантами, спрямованими на формування потреби у підвищенні рівня професійної культури.

Перспективи подальших наукових розвідок вбачаємо у розробці і впроваджені структурно-функціональної моделі формування професійної культури майбутніх фахівців у сфері цивільного захисту.

\section{ЛIТЕРАТУРА}

1. Вовк Н. Моральне самовдосконалення особистості фахівця служби цивільного захисту шляхом розвитку рефлексивних умінь під час навчання у вищих навчальних закладах ДСНС України /Н. Вовк, Т. Кришталь // Збірник наукових праць Національної академії державної прикордонної служби України, Серія:
Педагогічні та психологічні науки, Черкаси, 2015. - № 1 (74). - C. 51-69.

2. Коваль I. С. Формування особистості майбутнього фахівця в умовах навчального процесу / І. С. Коваль, О. Б. Бурак // Особистість в екстремальних умовах: зб. тез VI Всеукр. наук.-практ. конф. 3 міжнар. участю; 7 8.11. 2013 р., Львів. - Львів: ЛДУ БЖД, 2013. - С. 211 213.

3. Мельник I. Характеристика професійної культури спілкування майбутніх фахівців пожежної безпеки / Ірина Мельник // Збірник наукових праць Уманського державного педагогічного університету. Частина 3. 2012. - С. 208-215. [Електронний ресурс]: Джерело доступу: https://library.udpu.edu.ua/library files/ zbirnuk nayk_praz/2012/2012_3 29.pdf

4. Садковий В. Особливості професійної підготовки майбутніх фахівців у сфері цивільного захисту / В.Садковий, М. Горонескуль // Новий Колегіум. - 2016. - № 3. - С. 18-22.

5. Фільштейн Л.М. Професійна культура в аспекті підготовки фахівців / Л.М. Фільштейн, В.М. Журавльов // Наукові праці Кіровоградського національного технічного університету. Економічні науки. - 2016. Вип. 29. - С. 12-18.

6. Цибулько I. О. Особливості професійнопсихологічної культури фахівців цивільної авіації / Інна Олександрівна Цибулько // Вісник Національної академії Державної прикордонної служби України. - 2013. Вип. 3. - Режим доступу: http://nbuv.gov.ua/UJRN/ Vnadps_2013_3_41.

\section{REFERENCES}

1. Vovk, N. \& Kryshtal, T. (2015). Moralne samovdoskonalennia osobystosti fakhivtsia sluzhby tsyvilnoho zakhystu shliakhom rozvytku refleksyvnykh umin pid chas navchannia u vyshchykh navchalnykh zakladakh DSNS Ukrainy [Moral self-perfection of the personality of a specialist in the civil protection service through the development of reflexive skills while studying at higher educational institutions of the DSNU of Ukraine]. Journal of the National Academy of State Border Guard Service of Ukraine, Series: Pedagogical and psychological sciences. Cherkasy. Vol. 1(74). pp. 51-69. [in Ukrainian]. 
2. Koval, I. S. \& Burak, O. B. (2013). Formuvannia osobystosti maibutnoho fakhivtsia $\mathrm{v}$ umovakh navchalnoho protsesu [Formation of the personality of the future specialist in the conditions of the educational process]. Osobystist $v$ ekstremalnykh umovakh: $z b$. tez VI Vseukr. nauk.-prakt. konf. z mizhnar. uchastiu; 7-8.11. $2013 r$. - Personality in extreme conditions: Collection of theses of the VI All-Ukrainian Scientific-Practical Conference with international participation. 7-8.11. 2013, (pp.211-213). Lviv. [in Ukrainian].

3. Melnyk, I. (2012). Kharakterystyka profesiinoi kultury spilkuvannia maibutnikh fakhivtsiv pozhezhnoi bezpeky [Characteristics of the professional culture of communication of future fire safety specialists]. Journal of the Uman State Pedagogical University. Vol. 3, pp. 208 -215. [in Ukrainian].
4. Sadkovyi, V. \& Horoneskul, M. (2016). Osoblyvosti profesiinoi pidhotovky maibutnikh fakhivtsiv u sferi tsyvilnoho zakhystu [Features of professional training of future specialists in the field of civil protection]. Journal of the New Collegium. Vol. 3, pp. 18 -22. [in Ukrainian].

5. Filshtein, L. M. \& Zhuravlov, V. M. (2016). Profesiina kultura $\mathrm{v}$ aspekti pidhotovky fakhivtsiv [Professional culture in the aspect of training specialists]. Journal of the Kirovohrad National Technical University. Vol. 29, pp. 12-18. [in Ukrainian].

6. Tsybulko, I. O. (2013). Osoblyvosti profesiinopsykholohichnoi kultury fakhivtsiv tsyvilnoi aviatsii [Features of the professional-psychological culture of civil aviation specialists]. Journal of the National Academy of the State Border Guard Service of Ukraine. Vol. 3. [Electronic resource]. Available at:http:/nbuv.gov.ua/UJRN/Vnadps_2013_3_41. [in Ukrainian].

Стаття надійшла до редакції 29.10.2018

УДК 81’25:811.111:811.161.2

DOI:

Тетяна Ходутіна, студентка 2 курсу ОС “Магістр” Національного університету біоресурсів і природокористування України, м. Київ Лариса Колодіна, кандидат філологічних наук, доиент кафедри романо-германських мов і перекладу

Національного університету біоресурсів і природокористування Украӥни, м. Київ

\section{ОСНОВНІ ПРИНЦИПИ ПЕРЕКЛАДУ ТЕКСТІВ ОФІЦЙНО-ДІЛОВОГО СТИЛЮ 3 АНГЛІЙСЬКОЇ ТА УКРАЇНСЬКОЇ МОВ}

У статті проаналізовано спеиифіку перекладу офіиійно-ділового стилю. Визначено основні особливості, які слід враховувати під час перекладу. Охарактеризовано лексичні та граматичні особливості перекладу текстів офіційно-ділового змісту. У процесі дослідження було з'ясовано, щио найголовнішою вимогою перекладу є адекватність. При відсутності відповідників застосовуються лексичні та граматичні трансформації. Дослідження закономірностей перекладу офіційно-ділового стилю дає підстави стверджувати, що цеей стиль є одним із найважчих для перекладу, тому потребує уважності, обізнаності, ерудованості та фонових знань перекладача. Головною вимогою є передача думок та об' єктивності фактів, чітка визначена форма і правильне застосування перекладацьких трансформачій, які є суттєвим компонентом перекладачької компетентності.

Ключові слова: офічійно-діловий стиль; переклад; документ; трансформація; кліше.

Табл. 1.Літ. 7.

Tetyana Khodutina, the II st year Master Student,

National University of Life and Environmental Sciences of Ukraine, Kyiv

Larysa Kolodina, Ph.D.(Philology), Associate Professor of the

Romance and Germanic Languages and Translation Department,

National University of Life and Environmental Sciences of Ukraine, Kyiv

\section{BASIC PRINCIPLES OFTRANSLATION OF OFFICIAL-BUSINESS TEXTS IN ENGLISH AND UKRAINIAN LANGUAGES}

The research consists in determining the specifics of the official-business style translation. The translator must follow the strict rules and proper use of standard language templates, as well as know the features of official business communication, correspondence and business etiquette skills. The translator's actions for creating a translation text are called the translation process. It includes two stages: the study of the translator's content of the original text and the choice of the translation option. As a result of these stages, the transition from the original text to the text of the translation is carried out. The main features that must be taken into account during the translation are the use of vocabulary in the literal sense, the presence of phrases, stable phrases, cliches, words of foreign origin, modal verbs, adjectives, infinitive forms, abbreviations, non-equivalents vocabulary. The most important translation 